ISSN No. 0974-035X

An indexed refereed \& peer-reviewed journal of higher education

Towards Excellence

UGC-HUMAN RESOURCE DEVELOPMENT CENTRE

Gujarat University, Ahmedabad-380009, Gujarat, India

\title{
RESEARCH \& DEVELOPMENT OF PUBLIC-PRIVATE SECTOR WITH REFERENCE TO PROTECTION OF PLANT VARIETIES \& FARMER RIGHTS
}

\author{
Dr. Archana Thakur \\ Dr. Kshemendra Mani Tripathi \\ Mr. Arpit Sharma
}

\section{Perspective}

The main aim of this paper is to investigate the role of public and private sectors in registering their plant variety under different categories as well as mapping the role of public, private and farmer's right with reference to legal provisions. The graphical representation of data set of registered varieties (from 2009-2018) i.e. new, extant variety and farmer variety in a longitudinal way to analyze the participation of the public, private sector in registering the plant varieties. The finding of this study clearly indicates that during the initial year i.e. 2009-2012 not so many varieties got registered after that 2013-2018 specially in 2014 large varieties get registration in different categories. The finding gives a comparative viewpoint that initially in the year 2009 to 2012 public sector played a significant role in registration thereafter 2013-2018 private sector invest a lot specially in 2014 where large number of varieties register by farmers of Odisha with reference to their farmer's right. This research gives a clear depiction to the private industries a positive trajectory of benefit of registering the variety of plant under the PPV \& FR legislation. The Odisha case study enumerates the role of government and their public policies to encourage farmers to register their traditional variety and get benefit out of it.

Keywords: Public sector, private sector, farmer's right, categories of plant variety, Odisha case study. 
Towards Excellence: An Indexed, Refereed \& Peer Reviewed Journal of Higher Education / Dr. Archana Thakur, Dr. Kshemendra Mani Tripathi \& Mr. Arpit Shamra/ Page 1-12

“Indigenous varieties are our heritage and are the result of millennia of natural and artificial selections - Harlan 1975”

\section{Introduction}

The basic and premium objective of legislating Protection of Plant Varieties and Farmers' Rights Act, 2001(herein after referred as PPV \& FR) is to protect the human innovation of creators as an Intellectual Property Rights. The inclusion of PPV \& FR act is to give priority to breeders[1] of cultivators of crops which is not technically but practically improves the wide array of varieties of crops. The Act provides enthusiasm to the breeder not only to extent of new varieties but also extant variety[2] as well as farmer's variety[3] whereas in contemporary era also include essentially derived variety[4].

\subsection{Significance and need of PPV\& FR Act}

In the recent era after industrialization and inclusion of new technologies to make agriculture and horticulture more effective, a large mass of investment has been shown in the agriculture sector. The PPV \& FR Act, 2001 was formulated by law makers after understanding the demand for protection of innovations in plant varieties has opted sui generissystem[5] in compliance with Art. 27.3 of TRIPS Agreement, 1995[6]. The need of an hour has been observed by the government because of TRIPs which paved the half-way of the requirement of PPV \& FR, 2001. They are multiple key factors for need of legislation while observing the pace of need of agricultural development because public research institute for agriculture R \& D (research and development) having limited fund so that private organization is required for $\mathrm{R} \& \mathrm{D}$ in agriculture and private sector need incentive which can be withhold for them by intellectual property rights.

\subsection{Objective of PPV \& FR Act}

The legislative framework for the PPV \& FR act clearly demarcated the objectives are as follows:

a)To encourage the farmer to exercise their rights/innovations with reference to intellectual work placed by them or acquired the knowledge from their ancestors. 
Towards Excellence: An Indexed, Refereed \& Peer Reviewed Journal of Higher Education / Dr. Archana Thakur, Dr. Kshemendra Mani Tripathi \& Mr. Arpit Shamra/ Page 1-12

b)To stimulate the investment incurred by the breeder in the research and development of new varieties of plants, research and growth of the seed industry for boosting agricultural development.

c)To provide an effective system of protection categorically for plant varieties, plant breeders and rights of the farmers with respective to their hard work intellectual contribution.

\subsection{Theories applied in PPV \& FR Acts:}

The intent of the legislature to implement sui generis approach paves the way to determine farmer rights and acknowledges the intellectuality of farmers and their community if they produce any plant varieties. The theories which are considered by legislature while drafting the law on plant varieties is ownership theory rather than stewardship theory[7]. The objective of this approach laid down by legislature to opt ownership approach so that farmers should be granted intellectual property acknowledged just like commercial breeders. The ownership approach adopted by India as compared to other countries where stewardship theory is applicable in which the farmer will be the steward of the crop. The effectiveness of implementing both the approaches are concerned to be one of the studies which clearly recommended that stewardship approach is much better than ownership approach in Plant varieties[8].

\section{Review of Literature}

S. Bala Ravi [9] refers to intellectual property under the portion of Indian Patent Act, 1970 focused on innovation whereas exclusively it excludes all living forms by the definition of term invention. In an accurate manner explicitly a method of agriculture and horticulture was excluded from the list of patentable subjects. His research emphasizes the significance of sui generis law in PPV \& FR. His research majorly focus on private investment of improvement of crops and also focuses various international agreements on biodiversity and plant breeder's rights.

Suddir Kochhar[10] emphasizes enactment of sui generis law as IPR-savy and for public interest provision. This research basically gives cross sectional analysis of registration of crop under various categories which is expressly mentioned under PPV \& FR Act, definition clause 
Towards Excellence: An Indexed, Refereed \& Peer Reviewed Journal of Higher Education / Dr. Archana Thakur, Dr. Kshemendra Mani Tripathi \& Mr. Arpit Shamra/ Page 1-12

itself i.e. new varieties, extant varieties and farmer varieties. His research also criticized why Indian seed industry applied for a license for the seeds which are in public domain.

Manoj Srivastava, et al[11] emphasize on increased investment in the private sector which impacts due to PPV \& FR act. The research indicates and determines that the focus on public and private research trends previously filing for granting IPR in the public and private sector. The research effectiveness showed an impact of awareness of farmers and showed significance of convention on biodiversity. This research by analyzing the data showed a positive impact of rise of registration of application from 2007 to 2014 in various categories of variety registered under the legislation of PPV \& FR. They also cover separate graphical representation of data of framer variety application positive impact. The study specifically concluded after analyzing the data trends that the public sector is more inclined towards the protection of plant varieties.

MrinaliniKochupillai[12], study emphasizes on comparative analysis of provisions of PPV $\&$ FR in developed and developing nations. The research also brings an evaluator framework of comparing the history with the current scenario. The statistical data and its analysis gives an effectiveness of PPV \& FR in terms of public and private enterprises whereas it required effort form creating greater awareness among the farmer community so that there substantive amount of registration of application can be increased. The research also suggests making regulatory policy on focusing the non-hybrid and self-pollination.

Patricia [13] in his research IPR Regimes all over the world, farmers are not recognized as innovators, and it is the providers of technology who acquire Intellectual Property Rights which can be applicable to India that initially the seed bill, 2004 does not cover any farmer's right related to compensation whereas PVP \& FR, Act which clear demarcate that farmer does not have any rights related to compensation whereas in new legislation it is now being recognised by legislator.

\section{Research Gap}

The literature available on the research and development dimension in terms of public and private sector involvement in registration for certification of plant variety under PPV \& FR 
Towards Excellence: An Indexed, Refereed \& Peer Reviewed Journal of Higher Education / Dr. Archana Thakur, Dr. Kshemendra Mani Tripathi \& Mr. Arpit Shamra/ Page 1-12

Act, 2001 for various varieties is not projection clearly. The aim of this research is to identify efforts given by public sector enterprise and private sector enterprise in terms of certification under which category of varieties. These studies primarily suggest the agricultural industry for the benefits of certification by the public and private sector in which variety i.e. new variety, extant variety and farmer varieties till now (data set till 2018)[14].

\section{Methodology}

The methodology followed in this study is that the provisions of PPV \& FR act analyse and to understand the implementation of the provision, the author downloads the data for certification of plant variety under PPV \& FR Act and rules. Thereafter analyse the data by categorising into public and private units in which private also cover farmers' variety. The research accomplished on the given data set across the year from 2009 to 2018 to analyse how public and private sectors apply for grant of certification in different varieties.

\subsection{The criteria for registration of plant varieties}

The certification of plant variety can be achieved after compliance of the provisions under PPV \& FR, 2001 which is there in section 15[15]. The attribution of plant varieties are dependent on the DUS test and the distinctiveness means a variety atleast has one or more essential distinctive feature/s from the existence of present variety. The second prominent characteristic which can be tested for plant variety is uniformity which means that the variety should not change the basic characteristics for which distinctiveness is claiming. The attribute of the DUS test is stability which means that after repeated propagation of one another the variety may not lose its characteristic features. So the procedure which is laid down under PPV \& FR act which every variety shall have and passes it through the DUS committee which is being tested and certified for further mechanism. The last attribute of testing the plant variety is novelty which means newness or something new to the variety. The provision for DUS test notified under 'The Union for the Protection of New Varieties (UPOV), 1991' under article 7(distinctiveness), article 8(uniformity) and article 9(stability) are utmost significant for registration of plant variety.

\subsection{Analysis of Certification granted in a year}


Towards Excellence: An Indexed, Refereed \& Peer Reviewed Journal of Higher Education / Dr. Archana Thakur, Dr. Kshemendra Mani Tripathi \& Mr. Arpit Shamra/ Page 1-12

The process of issuance certification by an authority under PPV \& FR is there in Section 24 of PPV \& FR whereas the process of compliance for registration is in Chapter III. The concrete aim of making this act is to give protection to plant varieties, the rights of framer and breeder's right which encourage them to register new varieties, extant varieties and farmer varieties in order to strengthen them on a monetary scale. The table 1.1 contains the graphical illustration of data from the year 2009 to 2018 which clearly showed an upward trend till 2014 and after that there is uneven distribution of issuance of certificates. The reason for height attainment of certificate issue is directly proportional to farmer's awareness related to protection of their plant varieties. After 2014 there were crises and tough formation of issuance of certificates. The comparative cross-sectional analysis with time in terms of certification of seeds shown since 2009 to 2018 fairly increased which consist of many reasons and initiatives taken by different state governments.

Table 1.1

\begin{tabular}{|l|l|l|l|l|l|l|l|l|l|l|}
\hline Year & 2009 & 2010 & 2011 & 2012 & 2013 & 2014 & 2015 & 2016 & 2017 & 2018 \\
\hline Public & 168 & 50 & 80 & 154 & 154 & 250 & 64 & 112 & 55 & 111 \\
\hline Private & 19 & 0 & 9 & 58 & 150 & 583 & 321 & 493 & 317 & 409 \\
\hline
\end{tabular}

\subsection{Analysis of public and private enterprises}

The legislative frame-work which gives substantive rights to make an application by public \& private authorities [16] under PPV \& FR Act. The table 1.2 clearly showed an upward trend in 2009 private players under plant variety not entered in full extent whereas public enterprises played an important role for registration of PPV \& FR Act. But later on after analyzing the protection and profits from its private enterprise graph sharply increased. Even the government understood the requirement of private enterprise because of scarcity of funds. Interestingly, after 2013 private enterprise started inventing and we analyzed sharp growth of private 
Towards Excellence: An Indexed, Refereed \& Peer Reviewed Journal of Higher Education / Dr. Archana Thakur, Dr. Kshemendra Mani Tripathi \& Mr. Arpit Shamra/ Page 1-12

enterprise and farmers during these years applying for registration for different crops like majorly rice and cotton. The fundamental growth in terms of certification arises due to rights given to farmers as a breeder to register their seeds and get fair protection and monetary benefit under IPR. The sub-section (d) of section 16 of PPV \& FR Act gives an initial step for making an application by farmers and implementation of this law clearly gains momentum as we can see in table 1.3.

\begin{tabular}{|l|l|l|l|l|l|l|l|l|l|l|}
\hline Year & 200 & 201 & 201 & 201 & 201 & 201 & 201 & 201 & 201 & 201 \\
& 9 & 0 & 1 & 2 & 3 & 4 & 5 & 6 & 7 & 8 \\
\hline Public & 165 & 49 & 80 & 154 & 154 & 250 & 64 & 112 & 55 & 111 \\
\hline \multirow{2}{*}{ Private } & 19 & 0 & 9 & 58 & 150 & 583 & 321 & 493 & 317 & 409 \\
\hline
\end{tabular}

Table 1.2

*Private also includes farmers who apply for certification

\subsection{Analysis the varieties register under private sector}

The analytical discourse of private sector year-wise which gives a clear depiction that in the 2009 private sector was not so much contributing in plant variety under different categories i.e. new variety, extant variety, farmer variety. The situation changes in the year 2012 where there is significant growth of certification of private sector and after analyzing the data which clearly showed resultant that under private enterprise farmers are also applying for their rights. The increased trend of certification granted majorly arises due to farmer registration initially for cotton seeds and after that a large chunk of farmers get certification for rice and almost all are from Odisha. The legislative framework categorized plant varieties in different segments like new variety, extant variety and farmer variety.

\subsection{Analysis the varieties register under public sector}


Towards Excellence: An Indexed, Refereed \& Peer Reviewed Journal of Higher Education / Dr. Archana Thakur, Dr. Kshemendra Mani Tripathi \& Mr. Arpit Shamra/ Page 1-12

The varieties under PPV \& FR Act has its categories which has graphical representation in table 1.3 i.e. new varieties, extent varieties, farmer varieties. The analytical gives a clear depiction that public sector enterprises majorly focus on extant varieties till 2012 none of the certification was granted in new varieties, the reason countered is that new varieties required funding and tools which was the major hindrance for public sector enterprises. In the year 2013 there was a shift in the scenario and the government came up with different-different policies in order to implement the legislative framework of plant varieties. There are many agriculture institutions under public sector working for certification of plant varieties like Acharya N.G Ranga Agricultural University, Indian Council of Agricultural Research (ICAR), University of Agricultural Sciences, Dharwad, Karnataka. The public sector majorly focuses on 'extant variety' whereas in 2016 and 2018 there is a sharp paradigm shift of the public sector due to multiple collaborated projects which strengthened the policies. The focus now-a-days is on new varieties which give recognition in the global market about plant varieties and its distinctive feature attached to it.

\section{Odisha Case Study for Rice Variety}

While working on this research I came across the sudden registration of rice plant variety specifically in Odisha. The literature review and data gives a significant observation that why so many rice varieties got registered after 2013 in Odisha. The history itself gives a pointless knowledge that there are more than one lakhs varieties produced by local natives in different areas having distinctive characteristics. Apart from this, the government took an initiative to register the rights of farmers and assist them in all the ways so that they can take benefit from this.

The mechanism which the state has initiated to strengthen the process of certification of rice under PPV \& FR effort made by the Department of Agriculture. They realize that around 1250 varieties are still in existence then the government promotes by the way of awareness and also created a State Seed Testing laboratory which is also called to be Gene bank[17] in 2013 and one more gene bank was established in 2017 with a cost of Rs. 250 crores[18]. The main objective of this laboratory is to facilitate the farmer's seed conversation of seeds for favorable conditions. The purpose of creating this act is to formulate the structure which helps the breeder and farmer rights. The implementation of PPV \& FR clearly showed that after 2013 farmers 
Towards Excellence: An Indexed, Refereed \& Peer Reviewed Journal of Higher Education / Dr. Archana Thakur, Dr. Kshemendra Mani Tripathi \& Mr. Arpit Shamra/ Page 1-12

got awareness about the registration of plant variety which has significance of registration mainly in Odisha.

\section{Conclusion}

The resultant after an analysis the data from 2009 to 2018 for certification of public and private sector showed an uneven resultant whereas it is clearly shown that public participation was more during the initial year and private sector participation rose with time if we analyze it holistic way. Thereafter the study findings categorically sector-wise which clearly depict the trends that private sector which include farmers invest their funds for new, extant and farmer variety.

The categorical representation of data with reference to involvement of private sector that minor difference being shown in investment if we analyze year but there is substantive growth arises after the involvement of farmers variety in the year 2014. The state and seed crop which led to rise are Odisha and rice where numerous varieties were registered after 2014, the government took many initiatives in order to preserve the seeds and register them in PPV \& FR Act, 2001.

The graphical representation of data in terms of public sector enterprise that there is a transitional crest and tough in extant variety certification during initial year later on after 2014 there is a sharp increase of certification in new varieties by public sector enterprises. The government research on new varieties gained a significant amount of funding and recognition after being registered under PPV \& FR. 
Towards Excellence: An Indexed, Refereed \& Peer Reviewed Journal of Higher Education / Dr. Archana Thakur, Dr. Kshemendra Mani Tripathi \& Mr. Arpit Shamra/ Page 1-12

\section{Suggestion}

The research gap while reviewing the literature with related to PPV \& FR implementation is the suggestion from the present research are as follows:

1.The PPV \& FR rights cannot be fulfilled by making a legislation on it rather it requires awareness and support by the public-private sector.

2.The state government without being biased supports farmers for registration of crops and also initiates public private collaboration.

3.The implementation of this legislation till now is not widespread to whole of the country rather it is concentrated to particular state and crops which is again not the intention of legislature while framing it.

[1] Section 2 (c) of PPV \& FR which means a person or group of persons or a farmer or group of farmers or any institution which has bred, evolved or developed any variety.

[2] PPV\&FRAu/s 2 (j) (iii) and (iv) which means any variety is in public domain or about which there is a common knowledge.

[3] Section 2(1) of PPV \& FR act, 2001

[4] Section 2(i) of PPV \& FR act, 2001.

[5]Sudhirkochhar, "How Effective is Sui Generis Plant Variety Protection in India: Some Initial Feedback", Journal of Intellectual Property Rights · July 2010, <http://nopr.niscair.res.in/bitstream/123456789/10006/1/JIPR\%2015\%284\%29\%20273-284.pdf > (last accessed 19.05.2020).

[6] Members may also exclude from patentability: (a) diagnostic, therapeutic and surgical methods for the treatment of humans or animals; (b) plants and animals other than micro-organisms, and essentially biological processes for the production of plants or animals other than non-biological and microbiological processes. However, Members shall provide for the protection of plant varieties either by patents or by an effective sui generis system or by any combination thereof. The provisions of this subparagraph shall be reviewed four years after the date of entry into force of the WTO Agreement.

[7] Supra Note 5.

[8] Edited by Michael Halewood, Farmers' Crop Varieties and Farmers' Rights Challenges in taxonomy and Law, copyright material by Taylor and Francis

$<\underline{\text { https://www.bioversityinternational.org/fileadmin/user_upload/Farmers crop varieties-Halewood.pdf }>}$ 
Towards Excellence: An Indexed, Refereed \& Peer Reviewed Journal of Higher Education / Dr. Archana Thakur, Dr. Kshemendra Mani Tripathi \& Mr. Arpit Shamra/ Page 1-12

[9] S Ravi Bala, Effectiveness of Indian Sui Generis Law on Plant Variety Protection and its Potential to Attract Private Investment in Crop Improvement, Journal of Intellectual Property Rights Vol. 9, November 2004, pp. 533548.

[10] SudhirKochhar, How Effective is Sui Generis Plant Variety Protection in India: Some Initial Feedback, Journal of Intellectual Property Rights Vol 15, July 2010, pp 273-284.

[11]Manoj Srivastava, et al, Intellectual Property on Plant Varieties in India: A Sectional Analysis, Journal of Intellectual Property Rights Vol 20, March 2015, pp 81-88.

[12]MrinaliniKochupillai, The Indian PPV \& FR Act, 2001: Historical and Implementation Perspective, Journal of Intellectual Property rights, Vol. 16, March 2011 pp. 88- 101.

[13] Patricia KameriMbote, Community, Farmers' and Breeders' Rights in Africa: Towards a legal framework for sui generis legislation, University of Nairobi Law Journal (2003), P. 120

[14] List of certificate issued under PPV \& FR Act, 2001

$<$ http://plantauthority.gov.in/List_of_Certificates.htm> Last accessed on 20.05.2020.

[15] As per Section 15 of PPV \& FR, 2001 the criteria for registration of varieties involve characteristics which shall be test i.e. distinctiveness, uniformity, stability as it is necessary for registration.

[16]S. 16. Persons who may make application.- (1) An application for registration under section 14 shall be made by-

(a) any person claiming to be the breeder of the variety; or

(b) any successor of the breeder of the variety; or

(c) any person being the assignee of the breeder of the variety in respect of the right to make such application; or

(d) any farmer or group of farmers or community of farmers claiming to be the breeder of the variety; or

(e) any person authorised in the prescribed manner by a person specified under clauses(a) to(d) to make application on his behalf; or

(f) any university or publicly funded agricultural institution claiming to be the breeder of the variety.

(2) An application under sub-section (1) may be made by any of the persons referred to therein individually or jointly with any other person.

[17] Section 45 of PPV \& FR Act, 2001. 
Towards Excellence: An Indexed, Refereed \& Peer Reviewed Journal of Higher Education / Dr. Archana Thakur, Dr. Kshemendra Mani Tripathi \& Mr. Arpit Shamra/ Page 1-12

[18]Conservation of Genetic Resources of Indigenous Paddy Varieties of Odisha; An Initiative To Develop Potential Production Of Rice

$<$ https://rkvy.nic.in/Uploads/SucessStory/ORISSA/2018/2018032451Success\%20Story\%20-

Gene\%20Bank.pdf> last accessed on 27.05.2020.

\author{
Dr. Archana Thakur \\ Joint Secretary, University Grants Commission, New Delhi \\ \& \\ Dr. Kshemendra Mani Tripathi \\ Associate Professor of Law, Faculty of Law, Banaras Hindu University \\ \& \\ Mr. Arpit Sharma \\ Assistant Professor of Law, Institute of Law, Nirma University, Ahmedabad
}

